\title{
Influence of Preparation Conditions on the Morphology and Catalytic Activity of Hollow Spheres of Copper-Cerium Composite Oxide for Oxidation of Carbon Monoxide
}

\author{
Tetsuo Umegaki, Tomonobu ARAI, and Yoshiyuki KoJImA
}

(Received July 9, 2014)

\begin{abstract}
The present study investigated the influence of preparation conditions of hollow spheres of copper-cerium composite oxide on the morphology and catalytic activity for oxidation of carbon monoxide. The hollow spheres were obtained by a hydrothermal method using silica templates, and the homogeneity of the hollow spheres depended on the amount of urea used during preparation. X-ray diffraction studies indicated that the dispersion of $\mathrm{CeO}_{2}$ in the copper-cerium composite oxide increased with the addition of urea during preparation. In addition, X-ray photoelectron spectroscopy studies indicated that the amount of surface copper also increased with the addition of urea. The hollow spheres prepared with urea showed a higher catalytic activity for oxidation of carbon monoxide than the sample prepared without urea due to the morphological homogeneity, dispersion of $\mathrm{CeO}_{2}$, and surface composition of $\mathrm{Cu}$ species.

本研究では, 一酸化炭素酸化用球状中空銅 - セリウム複合酸化物の調製条件が形状や活性に与える影響について検討した。 球状中空銅一セリウム複合酸化物はシリカテンプレートを利用し, 水熱条件で調製し, その形状の均一性は調製時に添加する尿素 量に依存することが明らかになった。また, XRD 測定および XPS 測定の結果から球状中空体複合酸化物中の $\mathrm{CeO}_{2}$ の分散性お よび表面銅種の組成も調製時に添加する尿素量に依存することが確認された。尿素添加の効果は一酸化炭素酸化活性にも見られ， 尿素を添加した触媒で高活性を示すことが確認された。
\end{abstract}

Key Words

Hollow sphere; Copper-cerium composite oxide; Hydrothermal method; Oxidation of carbon monoxide

\section{Introduction}

The catalytic oxidation of carbon monoxide is an important reaction for many potential applications such as air purification devices for respiratory protection, pollution control devices for reducing industrial and environmental emissions, removal of trace quantities of carbon monoxide from enclosed atmospheres such as submarines and space crafts, carbon dioxide lasers, and fuel cell technologies ${ }^{1)} \sim 3$. Although oxidation of carbon monoxide has been traditionally carried out over supported noble metal catalysts, which offer excellent catalytic properties at low temperatures ${ }^{4)} \sim 11$ ), these catalysts undergo rapid deactivation in the presence of trace

Department of Materials \& Applied Chemistry,

College of Science \& Engineering, Nihon University

1-8-14, Kanda-Surugadai, Chiyoda-Ku, Tokyo 101-8308, Japan impurities and moisture. Moreover, owing to the high cost and low abundance of noble metals, recently, noble metalfree catalysts have been explored for the title reaction ${ }^{12}$. Specifically, base metals like copper and copper-based catalysts have attracted much attention in heterogeneous catalysis because of their superior catalytic activity toward oxidation of carbon monoxide and hydrocarbons ${ }^{13)} \sim 16$ ). Supported ceria can modify the catalytic behavior of an active metal through synergistic chemical and electronic interactions between the highly dispersed components. The adaptation of $\mathrm{CeO}_{2}$ with active copper metal leads to the formation of oxygen ion vacancies and decreases the redox potential of $\mathrm{Cu}$ species in the ceria matrix ${ }^{3}$. Ceria also provides the unique capability for oxidation reactions due to its facile generation of oxygen vacancies to form interfacial active centers. The surface oxygen vacancies of doped 
ceria and facile $\mathrm{Ce}^{4+} / \mathrm{Ce}^{3+}$ redox reactions are believed to be the driving force for this unique behavior. In general, the high activity of $\mathrm{CuO} / \mathrm{CeO}_{2}$ systems is attributed to strong interactions between $\mathrm{CuO}$ nanoparticles and the $\mathrm{CeO}_{2}$ support ${ }^{17)} \sim 20$ ).

Various reports examine the preparation of coppercerium composite oxide catalysts through methods such as impregnation ${ }^{12)}$, co-precipitation ${ }^{13)}$, sol-gel ${ }^{21)}$. The morphology of the composite oxide depends on the method used, and the catalytic activity for oxidation of carbon monoxide is influenced by the morphology. Luo et al. reported that the catalytic activity for oxidation of carbon monoxide increases with an increase in the specific surface area ${ }^{21)}{ }^{22}$. The dispersion of active copper species increased with the specific surface area, which in turn increased the oxygen vacancies to further increase the catalytic activity, which depends on the dispersion of active copper species and oxygen vacancies ${ }^{21)}{ }^{22}$. However, the relation between the catalytic activity and structure is not clear, and few reports have systematically investigated the relation. Here, we focus on hollow spheres because of their intrinsic properties such as simple morphology, easily controlled nano-structures, which we used to systematically investigate the relation.

In recent years, the preparation of core-shell solid and hollow microspheres with well-defined structures has attracted substantial interest because of their potential application in controlled drug delivery systems, lightweight fillers, catalysis, chromatography, vessels for confined reactions, and photonic band gap materials ${ }^{23)} \sim 28$ ). A number of efforts to develop new preparation methods have been devoted to generating colloids with core-shell structures, such as template-assisted sol-gel processes ${ }^{29}$ (30), layer by layer (LBL) techniques ${ }^{31)}{ }^{32}$, and microemulsion/interfacial polymerization strategies ${ }^{33) ~} 35$.

Previously, we investigated the fabrication and control of the nanostructure of hollow spheres such as metal oxidenickel ${ }^{36) ~}{ }^{39}$. We have also reported the fabrication of hollow spheres of copper-cerium composite oxide ${ }^{40}$. However, some of the hollow spheres are inhomogeneous, making it difficult to clarify the relation between the catalyst structure and activity.

The present work investigates the influence of preparation conditions on the morphology and catalytic activity of hollow spheres of copper-cerium composite oxide for catalytic oxidation of carbon monoxide.

\section{Experimental}

\subsection{Synthesis of silica templates}

Silica templates were prepared by a previously reported sol-gel methods ${ }^{41)}$. L(+)-arginine (Kanto Chem. Co., >
99.9\%, $0.0174 \mathrm{~g}$ ) was dissolved in deionized water (17.46 mL), and tetraethoxysilane (TEOS, Kanto Chem. Co., > 99.9\%, $1.108 \mathrm{~mL}$ ) was added to the aqueous solution. The solution was stirred at $323 \mathrm{~K}$ for $24 \mathrm{~h}$ to obtain a seed suspension of silica templates. The seed suspension was added to a solution of deionized water $(41.4 \mathrm{~mL}$ ) and ethyl alcohol (Kanto Chem. Co., > 99.9\% $169.33 \mathrm{~mL}$ ) containing L(+)-arginine (0.261 g). Subsequently, TEOS (11.08 mL) was added to the solution, and the resulting mixture was stirred at $323 \mathrm{~K}$ for $24 \mathrm{~h}$. The resulting suspension was dried, and the final product was obtained by calcination at $873 \mathrm{~K}$

\subsection{Synthesis of hollow spheres of copper-ceria composite oxide}

The obtained silica templates $(0.075 \mathrm{~g})$ were dispersed in $10.75 \mathrm{~mL}$ of distilled water, and then $0-4.22 \mathrm{~mL}$ of a $1 \mathrm{M}$ aqueous solution of urea (Kanto Chem. Co., > 99.0\%) and $0.5275 \mathrm{~mL}$ of a mixed solution of $\mathrm{Cu}\left(\mathrm{NO}_{3}\right)_{2} \cdot 3 \mathrm{H}_{2} \mathrm{O}$ (Soekawa Chem. Co., > 99.5\%) and $\mathrm{Ce}\left(\mathrm{NO}_{3}\right)_{3} \cdot 6 \mathrm{H}_{2} \mathrm{O}$ (Kanto Chem. Co., $>99.5 \%)$ with a weight ratio of $\mathrm{Cu} /(\mathrm{Cu}+\mathrm{Ce})=0.20$ were added to the suspension. The mixture was transferred into a $20 \mathrm{~mL}$ Teflon-lined stainless steel autoclave and maintained at $150^{\circ} \mathrm{C}$ for $15.0 \mathrm{~h}$. The copper-cerium composite oxide/silica template core-shell precursor was obtained by successive centrifugation (6,000 rpm, $10 \mathrm{~min}$ ), redispersed in deionized water, and dried in air at $373 \mathrm{~K}$ for $12 \mathrm{~h}$. To remove the silica templates, the precursor was leached in $5.0 \mathrm{M}$ of aqueous sodium hydroxide solution (Kanto Chem. Co., > 95.0\%, $20 \mathrm{~mL}$ ) for 48 h, with a fresh solution of sodium hydroxide ( $5 \mathrm{M}, 4 \mathrm{~mL}$ ) exchanged after 1 day. The hollow spheres were isolated by successive centrifugation (6,000 rpm, $10 \mathrm{~min}$ ), redispersed in deionized water, and dried in air at $373 \mathrm{~K}$ for $12 \mathrm{~h}$.

\subsection{Characterization}

The morphologies of the hollow copper-cerium composite spheres were observed using a Hitachi S-450 scanning electron microscope (SEM) equipped with a link energy-dispersive X-ray (EDX) analyzer operating at an acceleration voltage of $15 \mathrm{kV}$ and a Hitachi FE2000 transmission electron microscope (TEM) operating at an acceleration voltage of $200 \mathrm{kV}$. The crystalline phases of the samples after calcination were determined by X-ray powder diffraction (XRD) using a Rigaku MultiFlex X-ray diffractometer. X-ray photoelectron spectra (XPS) were acquired with an ESCA-3400 spectrometer (Shimadzu Corp.) equipped with a Mg Ka X-ray exciting source (1253.6 $\mathrm{eV}$ ) operating at $10 \mathrm{kV}$ and $10 \mathrm{~mA}$. The binding energies (BE) referred to the $\mathrm{C}$ 1s peak at $285.0 \mathrm{eV}$. 


\subsection{Activity tests}

Catalytic CO oxidation was performed on a tubular quartz microreactor using $10 \mathrm{mg}$ of catalyst. The feed gas consisted of $1.0 \% \mathrm{CO}$ and $0.5 \% \mathrm{O}_{2}$ in $\mathrm{N}_{2}$ with a total flow rate of $40 \mathrm{~mL}$ (NTP) $\mathrm{min}^{-1}$. The catalyst was directly exposed to the reaction gas for $1 \mathrm{~h}$ at each reaction temperature without any pretreatment. The reaction temperature was monitored by a thermocouple placed in the middle of the catalyst bed. The $\mathrm{CO}$ concentration in the reactor effluent was analyzed using a GC-8A gas chromatograph (Shimadzu Corp.) equipped with a thermal conductivity detector (TCD) attached to an SHINCARBON ST column

\section{Results and Discussion}

\subsection{Preparation of the catalyst}

Fast precipitation of copper-cerium composite oxides influences the inhomogeneity. Previously, homogeneous precipitates of cerium oxide or copper-cerium composite oxide particles were obtained by the addition of urea under hydrothermal conditions ${ }^{42}$, and it is possible that we also obtain homogeneous hollow spheres of coppercerium composite oxide by urea addition under the present preparation conditions. In order to confirm the effect of urea addition, we investigated the influence of the amount of urea on the morphology and structure of copper-cerium composite oxides. Fig. 1 shows the SEM images of copper- cerium composite oxides prepared with various amounts of aqueous urea solution. All samples in Fig. 1 were prepared with templates c.a. $400 \mathrm{~nm}$ in diameter. Compared with the SEM images of the samples prepared without urea (Fig. 1a), the samples prepared with urea consist of homogeneous spherical particles. The sample prepared with $1.06 \mathrm{~mL}$ of aqueous urea solution consists of spherical shells c.a. 500 $\mathrm{nm}$ in diameter and c.a. $50 \mathrm{~nm}$ in shell thickness (Fig. 1b), however, the spherical particles are not completely hollow spheres. The results indicate that the copper-cerium composite oxide was coated on each silica template; however, the oxide did not coat the entirety of the template because an insufficient amount of urea was coated on the template due to the limited coating time. The samples prepared with 2.11 and $4.22 \mathrm{~mL}$ of aqueous urea solution consist of hollow spheres with diameters c.a. 580 and $660 \mathrm{~nm}$ and shell thicknesses c.a. 90 and $130 \mathrm{~nm}$, respectively. These results indicate that homogenous hollow spheres of coppercerium composite oxide were obtained by the addition of specific amounts of urea. The chemical compositions of all samples analyzed by EDX are listed in Table 1. The fact that the silicon content does not vary between samples indicates that the amount of residual template does not depend on the amount of urea. On the other hand, the copper and cerium contents did vary. The sample prepared with $1.06 \mathrm{~mL}$ of aqueous urea solution gave the highest copper content, while the sample prepared with $4.11 \mathrm{~mL}$ of
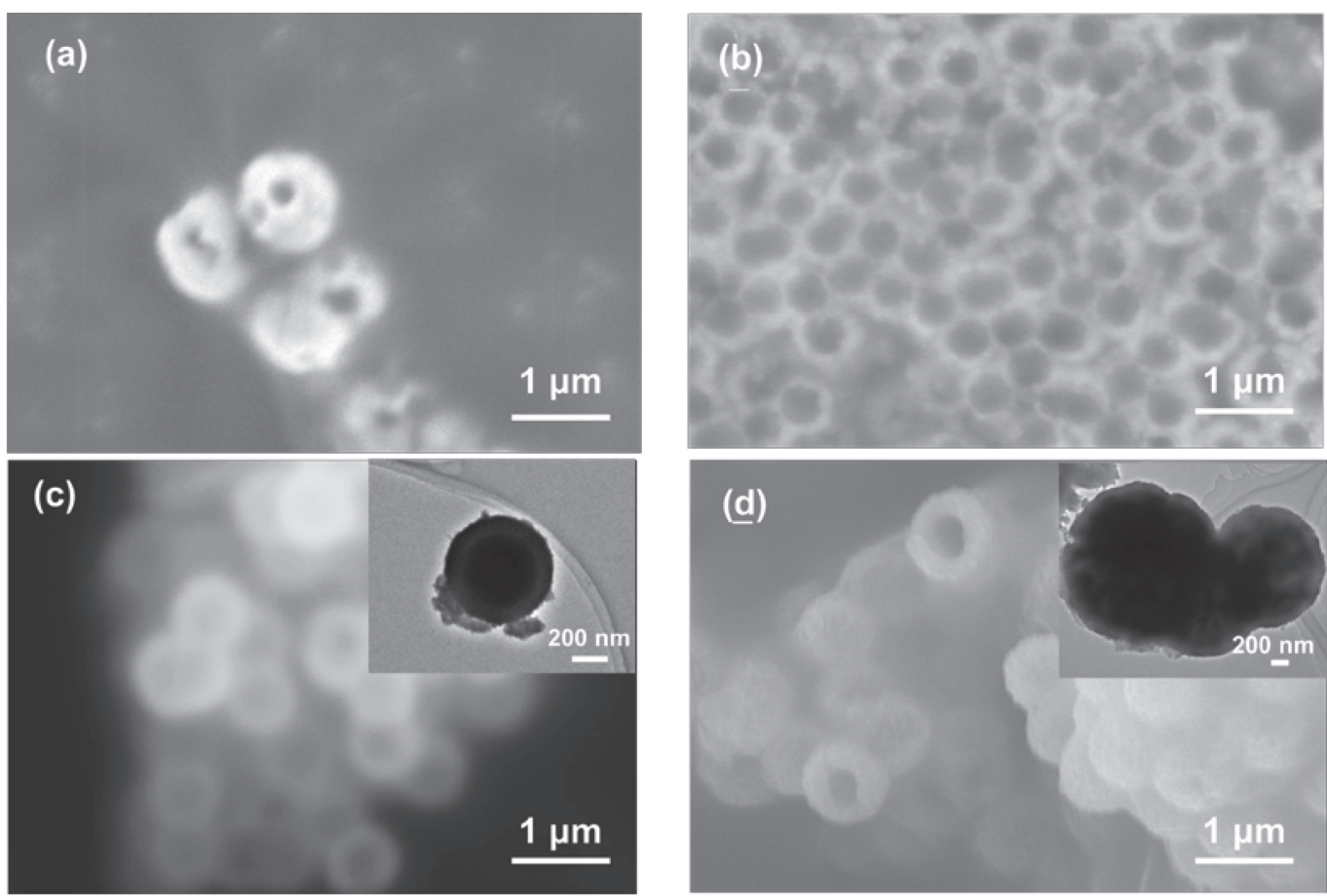

Fig. 1 SEM images of hollow spheres of copper-cerium composite oxide prepared with (a) 0, (b) 1.06, (c) 2.11 (inset, TEM image), and (d) $4.22 \mathrm{~mL}$ (inset, TEM image) of aqueous urea solution 
Table 1 Composition of catalysts prepared with various amounts of urea

\begin{tabular}{cccc}
\hline Urea aq. [mL] & Si[wt\% ] & Ce [wt\% ] & $\mathrm{Cu}[\mathrm{wt} \%]$ \\
\hline 0 & 6.7 & 83.2 & 10.1 \\
1.06 & 5.6 & 70.4 & 24.0 \\
2.11 & 6.3 & 81.5 & 12.2 \\
4.22 & 7.2 & 87.9 & 4.9 \\
\hline
\end{tabular}

aqueous urea solution gave the lowest copper content. The $\mathrm{pHs}$ of the solutions before hydrothermal treatment with 0 , 1.06, 2.11, and $4.22 \mathrm{~mL}$ of aqueous urea solution were 4.76 , $4.79,4.82$, and 4.86, respectively. Copper oxide was shown to effectively mix with cerium oxide in the sample with less urea because of the slower deposition of the composite oxide in the lower $\mathrm{pH}$ solution. Conversely, copper oxide does not effectively mix with cerium oxide in the sample prepared with more urea because of the relatively faster deposition of the composite oxide in the higher $\mathrm{pH}$ solution.

Crystalline structures of the samples were examined by XRD. Fig. 2 shows XRD profiles of the samples prepared with various amounts of aqueous urea solution. In all profiles, no peaks could be indexed to the copper species, suggesting that copper in the samples is well-dispersed and/or amorphous. The profile of the sample prepared without urea includes diffraction peaks at 28.8, 33.2, 47.6, and $56.6^{\circ}$, corresponding to the (111), (200), (220), and (311) planes, respectively, that can be indexed to the cubic fluorite structure of $\mathrm{CeO}_{2}$ crystals (JCPDS 34-0394). The diffraction peaks indexed to $\mathrm{CeO}_{2}$ crystals are not identified in the profiles of samples prepared with urea, indicating that amorphous and/or fine $\mathrm{CeO}_{2}$ crystalline phases were obtained by the addition of urea during preparation.

The $\mathrm{Cu} 2 \mathrm{p}$ and Ce 3d spectra, shown in Fig. 3 confirm the surface chemical states of the copper-cerium composite oxides prepared with various amounts of urea. No significant peaks are present in the $\mathrm{Cu} 2 \mathrm{p}$ spectrum of the sample prepared without urea, while peaks around 936 and $956 \mathrm{eV}$ ascribed to $\mathrm{Cu}^{2+43)}$ are observed in the spectrum of the sample prepared with urea. This result indicates that a larger amount of copper species exist in the samples prepared with urea compared with the sample prepared without urea. On the other hand, for the sample prepared with $4.22 \mathrm{~mL}$ of aqueous urea solution, the peak intensity ascribed to $\mathrm{Cu}^{2+}$ is significantly higher than that in the spectrum of the sample prepared without urea, though the copper composition is significantly lower than that in the sample prepared without urea. From the result shown in Fig. 2, it is supposed that the dispersion of $\mathrm{CeO}_{2}$ in the sample prepared with $4.22 \mathrm{~mL}$ of aqueous urea solution is higher than that in the sample prepared without urea. The results of the XPS, EDX, and XRD studies suggest that more copper species are located on the surface of the samples because $\mathrm{CeO}_{2}$ crystallites are very small and copper species tend to exist on the surface of the samples. Peaks centered at around 883, 890, 899, 902, 908, and $917 \mathrm{eV}$, observed in all Ce $3 \mathrm{~d}$ spectra, could be ascribed to $\mathrm{Ce}^{4+44)}$. The additional peaks centered around 887 and $904 \mathrm{eV}$, ascribed to $\mathrm{Ce}^{3+44)}$, were observed in the spectrum of the sample prepared with $4.22 \mathrm{~mL}$ of aqueous urea solution. $\mathrm{Ce}^{4+}$ species are mainly included in samples prepared with 0-2.11 $\mathrm{mL}$ of aqueous urea solution, while a certain amount of $\mathrm{Ce}^{3+}$ species are present in the sample prepared with $4.22 \mathrm{~mL}$ of aqueous urea solution. Surface $\mathrm{Ce}^{3+}$ species tend to increase with a decrease in the amount of copper species ${ }^{45}$. The results of XPS and EDX indicate that the sample prepared with $4.22 \mathrm{~mL}$ of aqueous urea solution includes a

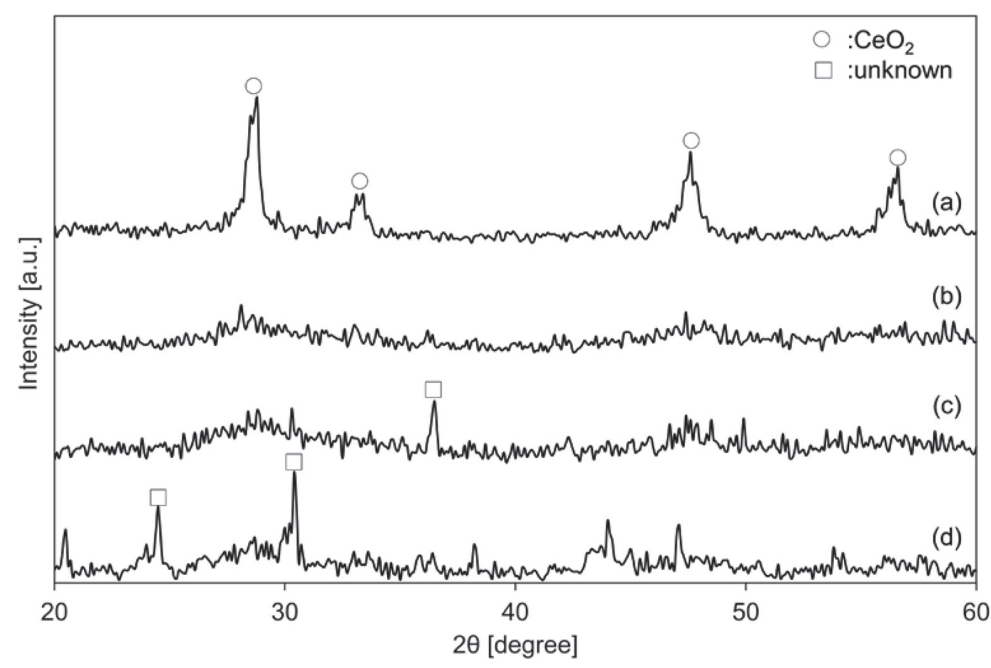

Fig. 2 XRD profiles of hollow spheres of copper-cerium composite oxide prepared with (a) 0, (b) 1.06, (c) 2.11 and (d) $4.22 \mathrm{~mL}$ of aqueous urea solution 

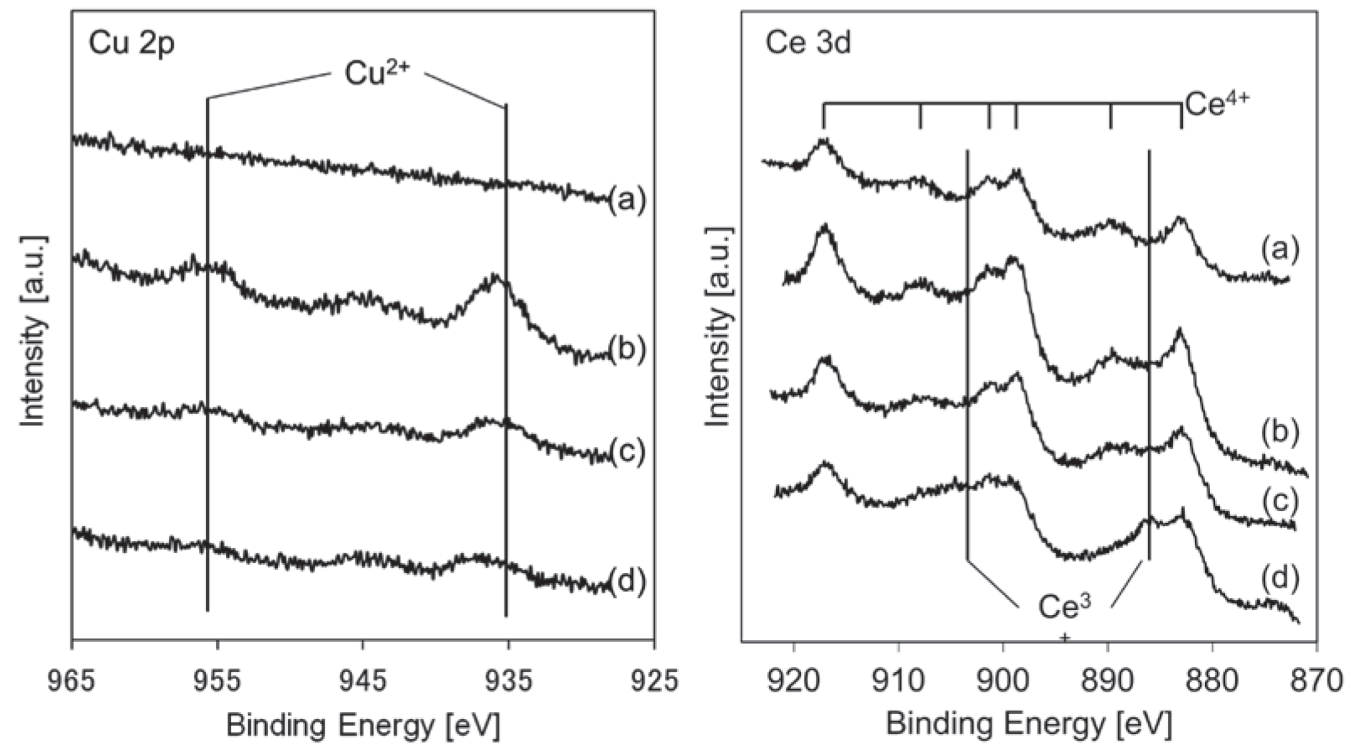

Fig. 3 X-ray photoelectron spectra in the $\mathrm{Cu} 2 \mathrm{p}$ and $\mathrm{Ce} 3 \mathrm{~d}$ region of hollow spheres of copper-ceria composite oxide prepared with (a) 0 , (b) 1.06 , (c) 2.11 , and (d) $4.22 \mathrm{~mL}$ of aqueous urea solution

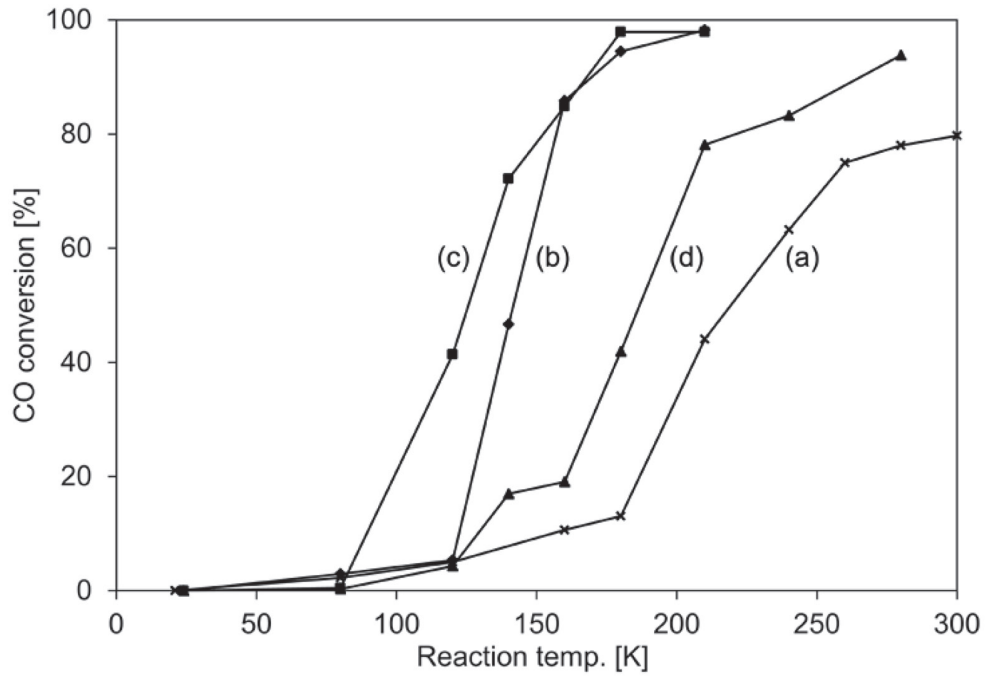

Fig. 4 CO conversion over hollow spheres of copper-cerium composite oxide prepared with (a) 0 , (b) 1.06, (c) 2.11, and (d) $4.22 \mathrm{~mL}$ of aqueous urea solution

relatively high amount of surface $\mathrm{Ce}^{3+}$ species.

\subsection{Catalytic activity}

Fig. 4 shows the catalytic performance of coppercerium composite oxide prepared with various amounts of urea. The catalytic activity for oxidation of carbon monoxide over the samples prepared with urea is higher than that over the sample prepared without urea. The samples prepared with urea include highly dispersed $\mathrm{CeO}_{2}$ and/or a high surface composition of $\mathrm{Cu}$ species, along with higher catalytic activity. The catalytic activity over the sample prepared with $2.11 \mathrm{~mL}$ of aqueous urea solution is the highest, while that over the sample prepared with $4.22 \mathrm{~mL}$ of aqueous urea solution is the lowest. The homogeneity of the hollow spheres, dispersion of $\mathrm{CeO}_{2}$, and amount of surface copper species can influence the catalytic activity and likely promote the high catalytic activity of the samples prepared with urea. The catalytic activity also depends on the amount of urea using during preparation. Increasing the amount of aqueous urea solution from $1.06 \mathrm{~mL}$ to $2.11 \mathrm{~mL}$ results in an increase in the catalytic activity while decrease in the amount of copper species. As seen in Fig. 1 (b) and (c), the sample prepared with $2.11 \mathrm{~mL}$ of aqueous urea solution includes homogeneous hollow spheres in contrast to the sample prepared with $1.06 \mathrm{~mL}$ of aqueous urea solution. These results suggest that the homogeneity of the hollow spheres largely influences the catalytic activity. Upon increasing the amount of aqueous urea solution to $4.22 \mathrm{~mL}$, 
the hollow spheres have thicker shells and a smaller amount of surface copper exists, as seen in Figs. 1 (d) and 3 (d). Reflecting on the morphological and surface states, the catalytic activity over the sample prepared with $4.22 \mathrm{~mL}$ of aqueous urea solution is lower than that over the samples prepared with 1.06 and $2.11 \mathrm{~mL}$ of aqueous urea solution.

\section{Conclusions}

The present study investigated the influence of preparation conditions on the morphology and catalytic activity of hollow spheres of copper-cerium composite oxide for oxidation of carbon monoxide. Hollow spheres of coppercerium composite oxide were obtained by a hydrothermal method; the homogeneity of the hollow spheres depended on the amount of urea used during preparation. The dispersion of $\mathrm{CeO}_{2}$ in the copper-cerium composite oxide and the amount of surface copper increased with the addition of urea during preparation. The hollow spheres prepared with urea showed higher catalytic activities for oxidation of carbon monoxide than the sample prepared without urea due to the morphological homogeneity, dispersion of $\mathrm{CeO}_{2}$, and surface composition of $\mathrm{Cu}$ species.

\section{Acknowledgement}

The research was financially supported by the Iwatani Naoji Foundation' s Research Grant.

\section{References}

1) Gamarra, D.; Belver, C.; Garcia, M. F.; Arias, A. M., J. Am. Chem. Soc., 129, 12064-12065 (2007)

2) Manzoli, M.; Monte, R. D.; Boccuzzi, F.; Coluccia, S.; Kaspar, J., Appl. Catal. B: Environ., 61, 192-205 (2005)

3) Harrison, P. G.; Ball, I. K.; Azelee, W.; Daniell, W.; Goldfarb, D., Chem. Mater., 12, 3715-3725 (2000)

4) Gardner, S. D.; Hoflund, G. B.; Upchurch, B. T.; Schryer, D. R.; Kielin, E. J.; Schryer, J., J. Catal., 129, 114-120 (1991)

5) Haruta, M.; Tsubota, S.; Kobayashi, T.; Kageyama, H.; Genet, M. J.; Delmon, B., J. Catal., 144, 175-192 (1993)

6) Bollinger, M. A.; Vannice, M. A., Appl. Catal. B:Environ., 8, 417-443 (1996)

7) Park, E. D.; Lee, J. S., J. Catal., 186, $1-11$ (1999)

8) Wolf, A.; Schuth, F., Appl. Catal. A:Gen., 226, 1-13 (2002)

9) Chen M. S.; Goodman D. W., Science, 306, 252-255 (2004)

10) Schryer, D. R.; Upchurch, B. T.; Sidney, B. D.; Brown, K. G.; Hoflund, G. B.; Herz, R. K., J. Catal., 130, 314-317 (1991)

11) Engel, T.; Ertl, G., Adv. Catal., 28, $1-78$ (1979)

12) Wan, H.; Li, D.; Dai, Y.; Hu, Y.; Zhang, Y.; Liu, L.; Zhao, B.; Liu, B.; Sun, K.; Dong, L.; Chen, Y., Appl. Catal. A: Gen., 360, 26-32 (2009)

13) Liu, W.; Flytzani-Stephanopoulos, M., J. Catal., 153, $304-$
316 (1995)

14) Reddy, B. M.; Rao, K. N.; Bharali, P., Ind. Eng. Chem. Res., 48, 8478-8486 (2009)

15) Reddy, B. M.; Rao, K. N., Catal. Commun., 10, 1350-1353 (2009)

16) Reddy, B. M.; Reddy, G. K.; Rao, K. N.; Khan, A.; Ganesh, I., J. Mol. Catal. A: Chem., 265, 276-282 (2007)

17) Meriani, S., Mater. Sci. Eng. A, 109, $121-130$ (1989)

18) Balducci, G.; Fornasiero, P.; Di Monte, R.; Kaspar, J.; Meriani, S.; Graziani, M., Catal. Lett., 33, 193-200 (1995)

19) De Leitenburg, C.; Trovarelli, A.; Zamar, F.; Maschio, S.; Dolcetti, G.; Llorca, J., J. Chem. Soc. Commun., 21, 21812182 (1995)

20) Trovarelli, A., Catal. Rev. Sci. Eng., 38, 439-520 (1996)

21) Luo, M. F.; Song, Y. P.; Lu, J. Q.; Wang, X. Y.; Pu, Z. Y., J. Phys. Chem. C, 111, 12686-12692 (2007)

22) Luo, M. F.; Ma, J. M.; Lu, J. Q.; Song, Y. P.; Wang, Y. J., J. Catal., 246, 52-59 (2007)

23) Caruso, F.; Caruso, R. A.; Möhwald, H., Science, 282, 1111-1114 (1998)

24) Jiang, P.; Bertone, J. F.; Colvin, V. L., Science, 291, 453457 (2001)

25) Gu, W.; Zhang, L.; Chen, H.; Shi, J., J. Am. Chem. Soc., 127, 8916-8917 (2005)

26) Wang, Y.; Xia, Y., Nano Lett., 4, 2047-2050 (2004)

27) Xu, X.; Asher, S. A., J. Am. Chem. Soc., 126, 7940-7945 (2004)

28) Yong Joo, K.; Mi Hyeon, L.; Hark Jin, K.; Gooil, L.; Young Sik, C.; Nam-Gyu, P.; Kyungkon, K.; Wan In, L., Adv. Mater., 21, 3668-3673 (2009)

29) Imhof, A., Langmuir, 17, 3579-3585 (2001)

30) Tissot, I.; Reymond, J. P.; Lefebvre, F.; Bourgeat-lami, E., Chem. Mater., 14, 1325-1331 (2002)

31) Nakamura, H.; Ishii, M.; Tsukigase, A.; Harada, M.; Nakano, H., Langmuir, 21, 8918-8922 (2005)

32) Duan, H. W.; Wang, D. Y.; Sobal, N. S.; Giersig, M.; Kurth, D. G.; Mohwald, H., Nano Lett., 5, 949 (2005)

33) Li, W.J.; Coppens, M. O., Chem. Mater., 17, 2241-2246 (2005)

34) Csetneki, I.; Filipcsei, G.; Zrinyl, M., Macromolecules, 39, 1939-1942 (2006)

35) Nakashima, T.; Kimizuka, N., J. Am. Chem. Soc., 125, 6386-6387 (2003)

36) Umegaki, T.; Takei, C.; Xu, Q.; Kojima, Y., Int. J. Hydrogen Energy, 38, 1397-1404 (2013)

37) Umegaki, T.; Takei, C.; Watanuki, Y.; Xu, Q.; Kojima, Y., J. Mol. Catal. A: Chem., 371, 1-7 (2013)

38) Umegaki, T.; Seki, A.; Xu, Q.; Kojima, Y., J. Alloys Compd., 588, 615-621 (2014)

39) Umegaki, T.; Ohashi, T.; Xu, Q.; Kojima, Y., Mater. Res. 
Bull., 52, 117-121 (2014)

40) Umegaki, T.; Yoshizawa, T.; Kojima, Y., J. Soc. Inorg. Mater. Japan, 20, 347-352 (2013)

41) Watanabe, R.; Yokoi, T.; Kobayashi, E.; Otsuka, Y.; Shimojima, A.; Okubo, T.; Tatsumi, T., J. Colloid Interface Sci., 360, 1-7 (2011)

42) Zhang, D.; Qian, Y.; Shi, L.; Mai, H.; Gao, R.; Zhang, J.;
Yu, W.; Cao, W., Catal. Commun., 26, 164-168 (2012)

43) Hwang, I. C.; Woo, S. I., J. Phys. Chem. B, 101, 4055-4059 (1997)

44) Scirè, S.; Crisafulli, C.; Riccobene, P. M.; Patanè, G.; Pistone, A., Appl. Catal. A: Gen., 417-418, 66-75 (2012)

45) Qi, L.; Yu, Q.; Dai, Y.; Tang, C.; Liu, L.; Zhang, H.; Gao, F.; Dong, L., Appl. Catal. B: Environ., 119-120, 308-320 (2012) 